\title{
Pattern of non-obstetric infectious recto-vaginal fistula: a case series and literature review in Cameroon, Central Africa
}

\author{
Pierre Marie Tebeu ${ }^{1,2,3}$, Roger Guy Michel Ekono ${ }^{2,4}$, Jovanny Tsuala Fouogue ${ }^{5 *}$, \\ Gregory Ekane Halle ${ }^{6,7,8}$, Joel Domgue Fokom², Charles Henry Rochat ${ }^{8}$
}

\author{
${ }^{1}$ Ligue d'Initiative et de Recherche Active pour la Santé et l' Education de la Femme, LIRASEF \\ ${ }^{2}$ Unit of Obstetrics and Gynaecology, University Teaching Hospitals, Yaoundé-Cameroon \\ ${ }^{3}$ Department of Obstetrics and Gynaecology, Faculty of Medicine and Biomedical Sciences, University of Yaoundé 1, \\ PO Box: 1364 Yaoundé, Cameroon \\ ${ }^{4}$ Department of Obstetrics and Gynaecology, Faculty of Medicine and pharmaceutical Sciences, University of Douala, \\ Cameroon \\ ${ }^{5}$ Douala Gynaeco-Obstetric and Pediatric Hospital, PO Box 7270 Douala, Cameroon \\ ${ }^{6}$ Unit of Obstetrics and Gynaecology, Douala General Hospital, Cameroon \\ ${ }^{7}$ Faculty of Health Sciences of the University of Buea, Cameroon \\ ${ }^{8}$ Geneva Foundation for Medical Education and Research, GFMER, Switzerland
}

Received: 01 May 2016

Revised: 04 June 2016

Accepted: 07 June 2016

\section{*Correspondence:}

Dr. Jovanny Tsuala Fouogue,

E-mail: fotsujo@outlook.com

Copyright: () the author(s), publisher and licensee Medip Academy. This is an open-access article distributed under the terms of the Creative Commons Attribution Non-Commercial License, which permits unrestricted non-commercial use, distribution, and reproduction in any medium, provided the original work is properly cited.

\section{ABSTRACT}

Background: Perineal infection is an uncommon cause of non-obstetrical recto-vaginal fistula (RVF) which is associated with HIV infection. Cameroon (Central Africa) is in the fistula belt but infectious RVFs have not yet been deeply studied in the country. We therefore sought to determine the pattern of non-obstetric infectious RVF in Cameroon.

Methods: We carried out a cross-sectional and descriptive review of non-obstetric infectious RVFs managed at the Yaoundé University Teaching Hospital between January 1, 2009 and December 31, 2015. All complete files were included. The following data were retrieved: socio-demographics, characteristics of the RVF, management and outcome.

Results: Five non-obstetrical and non-traumatic RVFs of which four were observed in HIV-infected patients were included. All those RVFs occurred spontaneously. The following predisposing factors were identified: perineal warts (one case out of five), perineal suppuration (two cases out of five), hemorrhoids (the HIV-negative patient), spinsterhood (all cases), unemployment (all cases). All HIV-patients were under anti-retroviral therapy (ART) with good immunological and clinical responses for three of them. Three of them underwent previous unsuccessful surgical cure. Management included ART, antibiotics and surgery. Surgical approaches were perineotomy alone or with martius' flap, procto-perineotomy or trans-vaginal advancement flap. Outcome was satisfactory for all HIV patients (closure of fistula and fecal continence).

Conclusions: Local infection is a rare cause of RVF which was associated with HIV in our series. Combined treatment including antibiotics, HAART and surgery gave good results.

Keywords: Non-obstetric fistula, RVF, Infection, HIV, Cameroon 


\section{INTRODUCTION}

HIV infection is a public health problem in Cameroon with a prevalence of $4.3 \%$ in the general population and $5.6 \%$ in women. ${ }^{1}$ HIV-related diseases are therefore expected. Acquired recto-vaginal fistula (RVF) in HIV positive children is a new and curious pathology in several developing countries. ${ }^{2-4}$ A case of HIV-related enterocolic fistula in an adult was reported for the first time in $2012 .{ }^{5}$

RVF is the presence of a communication between the vaginal cavity and the rectum, causing leakage of flatus and/or stool into the vagina. This is associated with unpleasant bodily odour leading to social stigma and ostracism. ${ }^{6}$ RVF accounts for $1-5 \%$ of genital fistulas. ${ }^{7-9}$ This type of genital fistula is associated with obstetrical and non-obstetrical (gynaecological) conditions. Infectious diseases affecting the perineum are the main non-obstetrical causes of RVF. Kouadio et al reported 37 cases of RVFs of which 11 were of infectious origin. ${ }^{10,11}$ Bankole et al. described 6 cases of pediatric infectious RVFs of which 5 were in HIV patients. ${ }^{2}$ Lymphogranuloma venereum, genital tuberculosis and perineal abscess have been identified by some authors as causes of RVF. ${ }^{10,12}$
Little is known about infectious RVF in adults. There is therefore a great need to explore this pathology. We herein report four cases of RVFs attributed to enterocolic infections in HIV patients.

\section{METHODS}

This study took place at the Yaounde university teaching hospital which also serves as referral hospital for the whole country (Cameroon). All patients who underwent surgery for RVF between January 1, 2009 and December 31,2015 were included. The site, size and borders of the fistula were confirmed by vaginal examination. The perineum was also examined in order to identify cutaneous and/or mucosal lesions. Management included combination of antibiotics, ART and surgery. The following surgical procedures were carried out: perineotomy, procto-perineotomy and trans-vaginal advancement flap (so called martius' flap). The following data were collected on a pretested questionnaire: including socio-demographic parameters, HIV status, past reproductive history, findings on perineal and vaginal exam, management and outcome. Prior to data collection, ethical and administrative clearances were obtained.

\section{RESULTS}

Table 1: Distribution of recto-vaginal fistula according to patients' characteristics.

\begin{tabular}{|c|c|c|c|c|c|}
\hline Characteristics & Patient A & Patient B & Patient C & Patient D & Patient E \\
\hline Age (years) & 31 & 37 & 33 & 36 & 39 \\
\hline Marital status & Unmarried & Unmarried & Unmarried & Unmarried & Unmarried \\
\hline Level of education & Secondary & University & Secondary & Secondary & University \\
\hline Profession & Blue collar & Blue collar & Blue collar & Blue collar & Blue collar \\
\hline Gestity & 2 & 3 & 7 & 2 & 1 \\
\hline Parity & 2 & 1 & 5 & 1 & 1 \\
\hline $\begin{array}{l}\text { CD4 cells count at time of } \\
\text { surgery (mirolitre) }\end{array}$ & 450 & 121 & 748 & $730 * * *$ & NA \\
\hline Taking HAART* & Yes & Yes & Yes & Yes & NA \\
\hline Drugs of HAART & $\begin{array}{l}* * \text { Tenofovir } \\
\text { lamivudine } \\
\text { lopinavir }\end{array}$ & $\begin{array}{l}\text { Zidovudine } \\
\text { stavudine } \\
\text { ritonavir }\end{array}$ & $\begin{array}{l}\text { Zidovudine } \\
\text { stavudine } \\
\text { nevirapine }\end{array}$ & $\begin{array}{l}\text { Tenofovir } \\
\text { lamivudine } \\
\text { effavirenz }\end{array}$ & NA \\
\hline Duration of HAART & **Five years & 1 week & 10 years & $\begin{array}{l}2 \text { years and } 2 \\
\text { months }\end{array}$ & NA \\
\hline Location of fistula & $\begin{array}{l}\text { Supra- } \\
\text { sphincteric } \\
\text { lower third }\end{array}$ & Sphincteric & $\begin{array}{l}\text { Supra-sphincteric } \\
\text { lower third }\end{array}$ & $\begin{array}{l}\text { Sphincteric } \\
\text { extending } \\
\text { to middle third }\end{array}$ & $\begin{array}{l}\text { Supras-phincteric } \\
\text { extending to the } \\
\text { lower third }\end{array}$ \\
\hline Fistula size $(\mathrm{cm})$ & 0.5 & 0.5 & 2 & 6 & 1 \\
\hline Duration of fistula & 1 year 6 months & 7 months & 7 years & 1 year & 2 years 5 months \\
\hline Number of surgical attempts & 2 & None & 1 & 4 & 0 \\
\hline Suspected causal germ & Herpes simplex & $\begin{array}{l}\text { Perineal } \\
\text { suppuration }\end{array}$ & Perineal suppuration & $\begin{array}{l}\text { Perineal } \\
\text { suppuration }\end{array}$ & Perineal suppuration \\
\hline Surgical technique & $\begin{array}{l}\text { Transvaginal } \\
\text { advancement flap }\end{array}$ & Perineotomy & Proctoperineotomy & $\begin{array}{l}\text { Perineotomy + } \\
\text { Martius graft }\end{array}$ & Proctoperineotomy \\
\hline Post-surgical follow up & One year & One year & One year & 5 months & Not available \\
\hline Outcome at last visit & Satisfactory & Satisfactory & Satisfactory & Satisfactory & Satisfactory $* * *$ \\
\hline
\end{tabular}


Five of the seven non-obstetrical RVFs recorded during the study period were attributed recto-perineal infection. All of them reported offensive vaginal discharge. Characteristics of patients are presented in Table 1. To protect medical secrecy, patients' names were coded as patient $\mathrm{A}$, patient $\mathrm{B}$, patient $\mathrm{C}$, patient $\mathrm{D}$ and patient $\mathrm{E}$. Patients A, B, C, D and E were respectively 31, 37, 33, 33 and 39 year old. None of the patients was married. patients $\mathrm{B}$ and $\mathrm{E}$ had attended university, while patients A, C and D ended studies in secondary school. All of them were Blue collar. Patients A, B and D were from the centre region, patient $\mathrm{E}$ from the North West region and patient $\mathrm{C}$ from the East region of Cameroon.

Patient A was gravida 2 Para 2002 (normal vaginal deliveries); patient B was gravida 3 para 1021 (normal vaginal delivery); patient $C$ was gravida 7 para 5025 (five normal vaginal deliveries); both patients D and $\mathrm{E}$ were gravida 1 Para 1001 (normal vaginal delivery). Four patients were HIV positive and were all under ART. Their CD4 cells counts were: 450 cells/microlitre $(\mu \mathrm{L})$ for patient $A, 121$ cells $/ \mu \mathrm{L}$ for patient $\mathrm{B}, 748$ cells $/ \mu \mathrm{L}$ for patient $C$ and 730 cells $/ \mu \mathrm{L}$ for patient $\mathrm{D}$. The duration of fistula was 18 months for patient A, 7 months for patient $\mathrm{B}, 7$ years for patient $\mathrm{C}, 1$ year for patient $\mathrm{D}$ and 2 years for patient $\mathrm{E}$. Patients $\mathrm{A}, \mathrm{C}$ and $\mathrm{D}$ underwent prior unsuccessful surgical cure for their RVFs.

Patient A presented herpetic perineal lesions around the fistula. Patient B, C and D had perineal suppuration before their formation of their RVFs, while patient $\mathrm{E}$ had had haemorrhoid before fistula formation. Patients A, C and $E$ presented with a hole of 0.5 to 1 centimeter $(\mathrm{cm})$ of diameter just above the sphincter at around $1.5 \mathrm{~cm}$ from the anal opening. Patient $\mathrm{C}$ has a hole of $2 \mathrm{~cm}$ involving the anal sphincter.

Surgery was the mainstay of management with the aim of closing the fistula. The following molecules were used for antibiotherapy: ceftriaxone, metronidazole, and amoxicillin-clavulanic acid. Surgical procedures were all carried out via vaginal route under loco-regional anaesthesia. Final outcomes were favourable for the five patients with complete closure and good continence.

\section{DISCUSSION}

\section{Prevalence}

Infection is an uncommon cause of RVFs in general but it is the most frequent cause of non-obstetrical RVFs. Indeed in 2014, we found that infection was responsible for $40 \%$ of RVFs managed in our setting. ${ }^{13}$ Our findings were similar to those reported by Kouadjio et al in Ivory Coast where $78.6 \%$ of non-obstetrical RVFs were attributed to infection. ${ }^{11}$

\section{Patient's characteristics}

All our patients were single and literate blue collar. They were thus from a low socio-economic background characterized by poor sanitation that increased their infectious risk. Eighty per cent (4 out of 5 cases) of our patients were HIV positive (under ART). In their series, Kouadio et al. found that $54.5 \%$ (6 out of 11 cases) of adults with RVFs were HIV positive. ${ }^{11}$ Bankole et al. reported acquired RVFs in 6 children of whom 5 were HIV positive. ${ }^{2}$ For several authors the high prevalence of HIV infection among patients with RVFs is due the contribution of immune deficiency to perineal infection. ${ }^{2,11}$

\section{Aetiology}

In our series the causes of RVFs were perineal suppuration and herpes simplex. Various causes of lower third RVFs have been reported: abscess of the rectovaginal septum, lymphogranuloma venerum, tuberculosis, abscess of bartholin's gland and HIVassociated bacterial and viral infections. ${ }^{10,11}$ In developed countries, the main cause of non-obstetrical RVF is Crohn's disease that is less frequent in tropical regions. ${ }^{12}$

\section{Anatomopathology}

All RVFs we herein report were located on the lower third of the rectum. This is similar to findings by Kouadjio et al. in Ivory Coast who described 7 pediatric RVFs all located around the anal sphincters. ${ }^{2}$

\section{Management}

Management included surgery and antibiotherapy (ceftriaxone and metronidazole followed by amoxicillinclavulanic acid for some patients). Outcome was favorable for all our patients with complete closure of the fistula and good anal continence. Kouadio GK et al in their series found that surgery plus antibiotherapy (amoxicillin or a quinolone plus metronidazole) yielded a success rate of $73 \%$ at first attempt. ${ }^{11}$ De Adams B et al. also described surgery as the best approach for the management of RVFs. ${ }^{11}$

\section{CONCLUSION}

Though infection is an uncommon cause of RVFs in general it remains the most frequent cause of nonobstetrical RVFs. Little is known about the latter but it seems to be highly associated with HIV. There is therefore a great need for further investigation.

\section{ACKNOWLEDGEMENTS}

We are grateful to the staff of the department of obstetrics and gynaecology of the Yaounde university teaching hospital. We also express special thanks to the medicosurgical centre of Yaounde, Cameroon. 
Funding: No funding sources

Conflict of interest: None declared

Ethical approval: The study was approved by the Institutional Ethics Committee

\section{REFERENCES}

1. National institute of statistics-Cameroon. Demographic, health and multiple indicators cluster survey 2011. Yaounde: institut national de statistique; 2012. Available at http://www.statisticscameroon.org/manager.php?id=6.

2. Bankole SR, Denoulet C, Coulibaly D, Mobiot ML, Angleret X, Sylla-koko F. La fistule rectovaginale acquise chez l'enfant: le VIH est-il la cause? Clinique. 1997;1772.

3. Borgstein ES, Broadhead RL. Acquired rectovaginal fistula. Arch Dis Child. 1994;71(2):165-6.

4. Banieghbal B, Fonseca J. Acquired rectovaginal fistulae in South Africa. Arch Dis Child. 1997;77(1):94.

5. Gill RS, Taylor G, Penner RM, Logsetty S. Enterocolic fistula: a rare presentation of cytomegalovirus infection. Can J Infect Dis Microbiol. 2012;23(2):e41-e43.

6. Tebeu PM, Kongnyuy E, Rochat $\mathrm{CH}$. Quality care for recto-vaginal obstetric fistula. The northern
Cameroon experience: case series and review of the literature. International Journal of Obstetric Trauma. 2011;23(4):387-94.

7. Devesa JM, Devesa M, Velasco GR, Vicente R, Garcia-Moreno F, Rey A, et al. Benign rectovaginal fistulas: management and results of a personal series. Tech Coloproctol. 2007;11(2):128-34.

8. McNevin MS, Lee PY, Bax TW. Martius flap: an adjunct for repair of complex, low rectovaginal fistula. Am J Surg. 2007;193(5):597-9.

9. Tebeu PM, Fomulu JN, Khaddaj S, de BL, Delvaux $\mathrm{T}$, Rochat $\mathrm{CH}$. Risk factors for obstetric fistula: a clinical review. Int Urogynecol J. 2012;23(4):387-94.

10. Debeche-Adams TH, Bohl JL. Rectovaginal fistulas. Clin Colon Rectal Surg. 2010;23(2):99-103.

11. Kouadio GK, Doumbia G, Turquin HT. Prise en charge des fistules recto-vaginales de l'adulte en milieu Ivoirien. Med Afr N. 2004;51(8/9):464-6.

12. Rivadeneira DE, Ruffo B, Amrani S, Salinas C. Rectovaginal fistulas: current surgical management. Clin Colon Rectal Surg. 2007;20(2):96-101.

13. Tebeu PM, Touka EB, Mawamba Y, Titapant C, Fomulu JN, Rochat CH. The pattern of non-obstetric fistula: a Cameroonian experience. Asian Pacific J Reprod. 2014;3(4):238-40.

Cite this article as: Tebeu PM, Ekono RGM, Fouogue TJ, Halle GE, Fokom JD, Rochat CH. Pattern of non-obstetric infectious recto-vaginal fistula: a case series and literature review in Cameroon, Central Africa. Int J Reprod Contracept Obstet Gynecol 2016;5:2239-42. 